In one case I found a poorly developed gland on the tip of a pointed trichome in an adult leaf, but this, though a very instructive intermediate stage, is certainly an exceptional occurrence. As a rule these points are well developed early in the ontogeny of the leaf, and it seems very doubtful whether each one passes through a primitive glandular stage in its development.

As regards the small glands still present, it may be pretty safely concluded that they are a somewhat retrograde condition of the primitive glands. One of such retrograde glands is represented in $f g .6$, of equal relative size with the other figures of trichomes. These are of much more frequent occurrence on the petiole, where also the stalked glands persisted longest unmodified, than on the lamina. It is also worthy of note that they reach their highest development at an earlier period in the unfolding of the leaf than do the rough warty points, another fact which gives evidence of their direct descent from a primitive structure.-Carleton E. Preston, Harvard University

\title{
SOME LITTLE KNOWN PLANTS FROM FLORIDA AND GEORGIA.
}

ThE collections made by Mr. A. H. Curtiss during the past summer contain a number of species, which apparently are unrecorded from Florida and Georgia. Among the more interesting of these are the following :

Najas Conferta A. Br. in Sitzungsb. Ges. Naturf. Fr. Berlin i 7 . I868. This species, formerly known only from Brazil and the West Indies, was found abundantly in tidal creeks near Milton at the head of Pensacola bay, Florida, August 3, i 90 i (no. 6858.)

Fimbristylis schoenoides Vahl. Enum. $2: 286$. An Indian and Australian plant collected by Mr. Curtiss in Walton co., Florida, in I886, and again on September 23, 1901, by roadsides and in miry spots near Milligan, Santa Rosa co., Florida (no. 6912).

Mayaca fluviatilis Aublet, Pl. Guian. I : 42. pl. 15 (M. Aubletii Schott \& Endl.) A species described from South America, but found fruiting by Mr. Curtiss in creeks at Milligan, Florida, September 24 (no. 6913). Readily distinguished from $M$. Aubletii Michx. (M. Michauxii Schott \& Endl.) by its very short thick peduncles.

Poepalanthus Pilulifer Koenicke in Mart. Fl. Bras. $3^{\mathrm{I}}: 4^{26}$. pl. 55. fig. I. Plants found by Mr. Curtiss in moist cultivated ground 
bordering Lake Louisa, Seville, Volusia co., Florida, September 3 (no. 6894), are identified with Koernicke's description and plate.

Atriplex Lampa Gillies ex Moq. in DC. Prodr. $3^{2}$ : iro. A South American species introduced upon ballast grounds near Pensacola (no. 6865).

Galenia Secunda Sond. in Harv. \& Sond. Fl. Cap. $2: 474$. A South African plant introduced and now forming broad mats in waste ground about Pensacola (no. 6869).

Ilex Decidua Walt. var. Curtissii.-Leaves as in the species, but when mature only $\mathrm{I}$ or $2^{\mathrm{cm}}$ long: berries smaller than in the species, 4 or $5^{\mathrm{mm}}$ in diameter.-Dryish land sloping to the Suwannee river-bottom, Branford, Florida, October 24, 1900 (no. 6736). According to Mr. Curtiss's notes the trees in the neighboring swamp had similarly reduced leaves. Again collected by Mr. Curtiss on Peace river, near Nocatee, De Soto co., Florida, April I 3, 190 I.

Sapium biglandulosum Muell. Arg. var. lanceolatum Muell. Arg. Linnaea $3^{2}$ : i 8 . A native of Brazil, Argentine Republic, and French Guyana, introduced in waste places at Pensacola (no. 6859).

Lechea Leggetti Britton \& Hollick, Torr. Cl. Prelim. Cat. N. Y. 6. In dry pine barrens near St. Marks, Wakulla co., Florida, July 25 , I 90 I (no. 6847). Rare or unrecorded south of Virginia.

Lythrum Curtissii.-Stems slender, glabrous, prominently 4 -angled, ascending and loosely branched above, 6 or $7^{\mathrm{dm}}$ high : leaves glabrous, thin, lanceolate to elliptic-oblong, short-petioled or subsessile; the the primary ones 2 to $5 \cdot 5^{\mathrm{cm}}$ long; those of the elongated slender branches mostly I to $\mathrm{I} \cdot 5^{\mathrm{cm}}$ long: flowers mostly solitary in the axils : calyx narrowly cylindric, slightly constricted at the throat, strongly ribbed, glabrous, $3^{\mathrm{mm}}$, becoming $5^{\mathrm{mm}}$ long, the deltoid-subulate lobes somewhat exceeding the bristle-like appendages : petals 6 , the oblongoval limb $2^{\mathrm{mm}}$ long, pale purple with a dark stripe: stamens longexserted.- In a miry swamp, Leary's, Georgia, August i 9, i 9o r (no. 6876), and formerly collected in Florida at Aspalaga, October I 897 (Chapman, no. 6r 70 of Biltmore Exsiccatae). Related to L. lanceolatum Ell., but of more slender flexuous habit, and with thinner leaves and fewer smaller flowers.

Sabbatia foliosa.- Perennial from elongated slender rootstalks, freely stoloniferous, the simple or loosely branching somewhat flexuous stems 2 to $5^{\mathrm{dm}}$ high : leaves very numerous, 8 to i 2 pairs below the lowest flowering branches, lanceolate to oblong-lanceolate, thin and 
wide-spreading, essentially uniform to the top of the plant, 2.5 to $6 \mathrm{~cm}$ long, 0.5 to $\mathrm{r} .2^{\mathrm{cm}}$ broad, mostly equaling or exceeding the internodes: flowers solitary and terminal or at the tips of the loosely ascending branches: calyx with 7 to ro lanceolate foliaceous lobes $\mathrm{I} .2$ to $2^{\mathrm{cm}}$ long: corolla rose-colored, with 8 to ro oblanceolate remote lobes I.3 to $2.5^{\mathrm{cm}}$ long and 5 to $7^{\mathrm{mm}}$ broad.- Swampy thickets on North Edista river, Orangeburg district, South Carolina, August 9, 1884 (John Donnell Smith); muddy banks of Blackwater river, near Milton, Florida, July 8, I 897 (A. H. Curtiss, no. 5928). Formerly called S. chloroides Pursh, from which it differs in its elongated rootstalk and more stoloniferous habit, its thin uniform leaves equaling the internodes, its foliaceous calyx lobes and narrower corolla lobes. From the habitally similar annual $S$. calycosa it differs in being perennial, in its larger usually ro-lobed corolla and narrower more numerous calyx lobes.

Scutellaria glabriuscula.- Stems two to several from a somewhat woody short caudex, slender and arcuate, simple or branching, 3 to $7^{\mathrm{dm}}$ high, minutely puberulent: leaves narrowly oblanceolate, mostly 2 or $3^{\mathrm{cm}}$ long, short-acuminate, narrowed to slender petioles 0.5 to $\mathrm{I} .5^{\mathrm{cm}}$ long, all but the lowermost entire, glabrous, viscid and glandularpruinose: inflorescence racemose or racemose-paniculate, with reduced linear or linear-lanceolate floral-leaves: pedicels 2 to $4^{\mathrm{mm}}$ long, puberulent and occasionally with scattered stipitate glands : calyx glandular-pruinose, minutely puberulent on the angles and margins: corolla $2.5^{\mathrm{cm}}$ long, glabrous, the slender tube and obliquely flaring throat whitish, the lips purplish.- Dry sandy pine-woods, Walton co., Florida, September 15, I886, and dry scrub lands near De Funiak springs, Walton co., September 2 I, I 90 I (A. H. Curtiss, nos. 3, 6907); pine-barrens, Westville, Holmes co., Sept. r 8, г90 г (A.H.Curtiss). Related to $S$. integrifolia L., but differing from that in its more slender less pubescent stems, narrower slender-petioled glabrous leaves and subglabrous calyx; and from S. integrifolia and its immediate allies in its glabrous corolla. S. integrifolia, a plant of moist soils, flowers in spring and early summer, while $S$. glabriuscula grows only in dry soil and flowers in autumn.

Perilla ocymoides L. Gen. ed 6. 578. An Indian species reported by Mr. Curtiss as "abundant in streets of various towns in northwestern Florida and southwestern Georgia. In low woods near Bainbridge, Georgia." Collected August I4, I901, at Bluff springs, Florida (no. 6874). 
Pluchea Quitoc DC. Prodr. 5:450. Native of Brazil and Chili. Collected by Mr. Curtiss on ballast at Pensacola in r886, and on August I2, I90I, found established in moist ground near Pensacola (no. 6873).

Cacalia sulcata.-Stem I to $\mathrm{I} .5^{\mathrm{m}}$ high, deeply furrowed: leaves from ovate to ovate-oblong, glabrous, green on both sides, faintly nerved; the lowest long-petioled, blunt and undulate-dentate; the upper sessile, acuminate, deeply and coarsely acuminate-serrate: coryunb broad and loosely branched: the narrowly campanulate involucre of 5 oblong bluntish bracts 8 or Io $^{\mathrm{mm}}$ long; the pedicels minutely calyculate-bracted : corolla deeply cleft.-Clearings in edge of swamp near Smithville, Georgia, August 26, r9o I (A. H. Curtiss, no. 6884 A). Related to $C$. ovata Ell., but differing in its deeply furrowed lower green stem; green, not glaucous, more cut leaves; and later flowering season--the taller glaucous $C$. ovata with unfurrowed stem flowering some days earlier in the same region.-M. L. FERNALD, Gray Herbarium.

\section{THE MORPHOLOGY OF THE PINE CONE. ${ }^{4}$}

(With PLATE VIiI)

So MUCH has been said in regard to the morphology of the cone of the pine and its near allies that it would seem impossible as well as unnecessary to suggest anything further. However, the recent excellent summary in Coulter and Chamberlain's "Morphology of the Spermatophytes" of the many theories hitherto advanced to clear up the matter, and the conclusions reached by the authors named, show that it is by no means settled, and perhaps warrant me in presenting an interpretation which I have used in lectures before my own classes for half a dozen years or more.

The point at issue is, in short, the morphological nature of the so-called "ovuliferous scale," a structure present in the cones of the Abietineae, but rudimentary or wholly wanting in the other tribes of the Pinaceae. In a pine cone the axis bears bracts which are the homologues of the stamens in the staminate cones, and in addition to these bracts there are thick, woody scales (one immediately above each bract) which bear the seeds. In such a seed-bearing cone the woody

${ }^{4}$ Read before Section G, Botany, of the A. A. A. S., Denver meeting, August, I90I. 